\title{
Pre-Election Discourse as a Special Type of Institutional Discourse
}

\author{
Venera N. Yapparova ${ }^{1}$, Juliya V. Ageeva $^{2}$, Atirkul Y. Agmanova ${ }^{3}$ \\ ${ }^{1,2}$ Kazan Federal University, Lev Tolstoy Institute of Philology and Intercultural Communication; \\ ${ }^{3}$ L.N. Gumilyov Eurasian National University, Kazakhstan \\ Email: venera2306@mail.ru, Contact:89178850951
}

\section{Received: 21st October 2017 Accepted: 16th November 2017, Published: 31st December 2017}

\begin{abstract}
The modern unstable geopolitical situation in the world draws the attention of researchers from various scientific fields to a comprehensive study of political communication issues. The importance of the political sphere of human communication and life necessitates the study of the linguistic features of political discourse at the present stage of its development. The most mobile and volatile is the pre-election discourse which motivates the need to identify the specifics of the texts of election campaigns. In addition, it is in the course of the struggle for power when participants of political communication apply all kinds of, sometimes unexpected or innovative, linguistic and extralinguistic means to achieve their goal. In this paper, the authors analyze existing interpretations of the definition of "political discourse" and describe its universal and specific features. Observations and conclusions made by the authors of the article are based on extensive empirical material, namely on a comprehensive analysis of 5000 thousands publications of different genre devoted to the elections to the State Duma and the election of the President of the Russian Federation. During the analysis, the authors found that the universal characteristics of the pre-election discourse include such features as historical variability, stereotypeness, presence of cliché, rigidity, intentionality, wide application of slogans, and also polemicism and manipulativeness. Among the specific features of the discourse under study, the use of metagraphic means, metaphoricality, the use of counterposing and comparison techniques, the ironic transformation or deformation of precedent texts, the frequency use of the subjunctive mood and imperative constructions are primarily distinguished. Certainly, the linguistic and non-linguistic features listed in the paper are not exhaustive and do not pretend to be complete, since pre-election texts are dynamic entities which content and characteristics can vary depending on the goals and objectives of institutional communication and the political situation as a whole.
\end{abstract}

Keywords: Political Discourse, Pre-election Discourse, Institutional Discourse, System-Forming Features of Discourse, Political Communication

\section{Introduction}

The discourse theory is one of the most actively developing areas of modern linguistics. A lot of research has been devoted to the study of discourse, the authors of which interpret this phenomenon from different points of view and analyze various types of particular discourses functioning in modern public life [1-8].

A considerable number of Russian and foreign researchers are engaged in the study of political discourse. The interest in political discourse, according to A.N. Baranov, is determined by three factors: 1) the internal patterns of development of the linguistic theory itself, which could not ignore such a sphere of functioning of the language system as politics; 2) the need of political science for the methods of analyzing political texts and media texts for monitoring various trends in the public consciousness; 3 ) the social order associated with attempts to save political communication from manipulation by the public conscience [9, 245].

Political discourse attracts the attention of researchers also insofar as in this research paradigm, not the intrasystem language relations are brought to the fore, but the characteristics of the linguistic personality as the bearer of the corresponding culture and status-role relations.

However, despite the increased attention to political discourse, until now there is no generally accepted definition of this term in science. Different scientists offer their definitions for the language of politics, that are encountered in research along with the term "political discourse". In most works, the terms "political language", "political communication" and "political discourse" are used almost interchangeably. According to E. I. Sheigal, the terms "political communication" and "political discourse" can be used as non-strict synonyms [10, 29]. However, the researcher also talks about the need to distinguish between the concepts "political language" and "language of politics". E. I. Sheigal writes that political language should be seen as a "resource open to all members of the language community" [10,33]. The term "language of politics" is understood by the researcher as "terminology and rhetoric of political activity where politicians act in their professional role (like the discourses of other professional spheres: religion, medicine, justice, etc.)" [ibidem].

Thus, an analysis of existing political discourse studies allows us to say that this concept can be interpreted in two ways: both in the broad, and in the strict senses.

In a broad sense, political discourse is defined as "the sum of speech works in a certain paralinguistic context: the context of political activity, political views and beliefs, including its negative manifestations (avoidance of political activity, lack of political convictions)" [11, 22]. 
In the strict sense, political discourse does not go beyond the sphere of politics. According to this approach, political discourse is a discourse of politicians, that is, "discourse is political when it accompanies a political act in the appropriate institutional setting" [Ct. 12, 128].

In this paper, it seems logical to proceed from a broad understanding of political discourse, including in it after E. I. Sheygal, both institutional and noninstitutional forms of communication, in which at least one of the three components belongs to the sphere of politics: the subject, the addressee or the content of communication.

Accordingly, the pre-election discourse is a kind of political discourse in the process of political agitation of citizens for their decision to vote for a certain candidate.

\section{Methods}

Observation method, continuous sampling method, descriptive-analytical, lexical-semantic and contextual methods, as well as classification and systematization methods, and also quantitative processing of linguistic data were used to identify the universal and specific properties of the pre-election discourse.

\section{Results}

5 thousands of different genre publications posted in Internet resources and in the Russian media during the preparation and conduct of election campaigns for the State Duma of the V convocation in 2007 and for the election of the President of the Russian Federation in 2008 have been analysed in the course of a comprehensive study. The analysis of the texts studied showed that the pre-election discourse has universal characteristics inherent in any institutional discourse, and also has its own specific extra-linguistic and linguistic features.

\section{Discussion}

The discourse of struggle is "a complex communicative phenomenon, which represents the process of forming a conceptual picture of the subject and object of power in political elections" [13, 35].

The main intention of the pre-election discourse is the struggle for power which can be obtained and retained, with the support of a large number of voters, what also makes it possible to consider the struggle for the votes of the electorate as an important goal of the preelection discourse.

Pre-election discourse (PD), like any other institutional type of discourse, has universal and specific features. Due to the institutional nature of the pre-election discourse, one can speak of its historical variability caused by the possible disappearance or transformation of already existing types of political institutions, or with the appearance of their completely new varieties. The pre-election discourse is built according to certain patterns, so it is characterized by stereotypeness, although it can be expressed in different degrees, which is primarily due to the fact that in the actual situation of communication, the prototypical order of discourse is often violated.

One of the universal features of the pre-election text is also wide application of cliché in it, as any institutional type of discourse is a specialized, full of cliches, version of people's communication that are forced to communicate in accordance with the norms of the given society [14, 203]. Closing his or her speech, the speaker, as it were, puts on the mask of the representative of an institutional group.

The conditions for a contracted representation of information in pre-election texts also determine rigidity of a pre-election discourse. Stamps and stereotypes of thinking and speech contribute to creating a sense of acceptability of information in a pre-election discourse; they are identified with a certain automatism of perception.

Taking into account the intentional basis of a preelection discourse, there are distinguished such its features as, for example, polemique, collective authorship, manipulativeness. Each pre-election text is polemical, because it contains the desire to express and confirm one's own opinion in opposition to the opinions of opponents, to agree or, more often, not to agree with the existing state of affairs in the country, to challenge the existing political order or its competitors. A pre-election discourse does not have an author as such since it covers, first of all, the whole electoral process and the texts that arise during it. In the opinion of M.V. Ilyin, something integral appears as a result of a collision of several participants' wills, each of which produces something in a joint discourse. As a result, this "discourse is the product of many authors" [15, 94].

In addition, any pre-election text is manipulative in its nature, since it carries out the task of providing a covert influence on potential voters.

In addition, a pre-election discourse, like any institutional discourse, has its own sublanguage (special vocabulary, phraseology and paremiology) $[10,25]$. The use of a variety of language tools in the pre-election discourse is connected, first of all, with the implementation of manipulative influence on the addressee of pre-election texts, that is, on the electorate.

The special use of linguistic means in a pre-election discourse is manifested at various levels of the language: phonographic, lexical, grammatical and textual.

At the phonographic level, the meta-graphic means is often used in pre-election texts (underlining, font selection, capital letters). Boldface is used mainly to highlight the main positions of the electoral program or individual words on which attention is focused. The capital letters are used most often when writing slogans. For example: "LDPR. Do not lie and do not be afraid!","PEACE AND BREAD EVERY HOME!", "Discoveries in the energy sector are the creation of new types of energy creating completely new opportunities for the organization of people's living space". 
Speech manipulation at the lexical level is realized with the help of lexico-semantic, lexical-syntactic, and lexical-pragmatic means.

The lexical-semantic means includes those based on the correlation of a word (or its equivalent) and the subject-conceptual content that it expresses. The close attention of researchers is drawn to the study of the metaphorical component of a political discourse, what allows us to recreate the metaphorical picture of the political world. For example: "... two parties did not think of anything else, but to try to hide behind the back of the President, and this is a shame for any political structure. The third party is still hiding behind the back of $K$. Marx" [http://www.ldpr.ru/events/election].

In a political text, there is not necessarily to have a single dominant model, most often there are a few of them, and they can have in the capacity of their sources the frames that relate to different areas of experience. Lexico-syntactic means of manipulation depend on the peculiarities of the relationship between linguistic signs. They belong to groups of words with special semantic relationships (synonyms, antonyms, hyperonisms), with the use of contrast and comparison, combinatorial changes of "ready" expressions. For example:

1) synonyms: "Simple ordinary Communists, you are deceived! We never lied to you. LDPR is the only party that does not lie! " [ibid.];

2) antonyms: "Joining the European Union is not fantastic at all. This is a reality for most countries of the former socialist camp" [http://www. democrats. ru]; 3) opposition "us-them, good / bad, comic / tragic, hero / anti-hero": "Europe came together in a warm part of the continent, being surrounded by seas, rapidly developing, sucking everything possible from the colonies of Latin America, Africa and Asia. Having enriched due to this, it had managed to create favorable conditions for the lives of half a billion citizens of all European countries, those who are now a part of the European Union. We were not lucky. We have a very cold climate, severe conditions of life and eternal war" [http://www. ldpr. ru/events/election]; If you think that everything is fine in this life, vote for the candidate from "United Russia", for the candidate from the party of oligarchs and officials. If you think that you need to change something in this life, support the CPRF - the party of the working people. Other candidates are tanglefoots for catching voices and distracting attention from the burning problems of our country [http: //kprf. ru/personal/zyuganov/prog/53766. html?s].

4) comparison: "Everything was done from above: the tsar, the secretary general, the president and the small group of officials surrounding them. And below, the people are like a herd, and they are above, like shepherds" [http://www. ldpr. ru/events/election];

5) the ironic transformation or deformation of the meaning of well-known precedent texts: "In our history we jumped into one deep end and then into another" [ibid.]; "The president clearly rendered a bear's service to the "bears", and he put himself in a disadvantageous light, if not ridiculous" [http://www.kprf.ru/vibory2007/chronicle/53117.html.] ; "Daily Journal" about the sharp drop in the rating of "United Russia": "Got stuck in Putin" [http://www. kprf. ru/vibory2007/chronicle/53105. html].

The impact of lexical-pragmatic means is mainly based on the transfer of an author's relationship to the object. The pragmatic aspect of lexical units includes an expressive-emotional assessment and various connotations. First of all, these are words with an estimated connotation, and contextual evaluation words, various ways of implementing a negative and positive secondary nomination (euphemisms, melioratives, nicknames, dysfemism, labels, peyoratives, etc. ). For example, in the 2007 election campaign, representatives and supporters of the United Russia Party received the largest number of all kinds of nicknames and labels: the Putintsy, the Yedinorosses, the Bears, "Kremlyads" (the Kremlin's whores), Eduny Rossii (the Eaters of Russia), Putin ... as noncommissioned officer's widow","Putin ... Is this man the Antichrist ...", etc.

Stylistic diversity and disinhibition of speech toward the lowering of style is also characteristic for modern pre-election texts. Let compare: "Now we understand, we can not long endure one dynasty (300 years), one political regime (74 years), and we do not have to shuffle ourselves from one extreme to another", "Today they want to deceive you again, to worm themselves into authorities" http://www. ldpr. ru/events/election].

At the grammatical level, features of morphology and syntax are widely used. For example, the verb tense, the subjunctive mood, the imperative, the number of a noun, and other morphological means. In the preelection text created for the purpose of agitating the electorate, a special role is played by imperative constructions, which are of a cautionary or recommendatory nature. Let compare: "Remember: our number on the ballot paper is 6 !" [http://www. rg. $\mathrm{ru} / 2007 / 11 / 16 /$ pss. html ]. In modern linguistic studies, there has been a change in the character of the modality toward recommendatory, indirectly imperative, and not openly-edifying. Let compare: "Let 's choose the worthy people!" [http://www. pp-pss. ru/main. php?ID=405339]; "I invite you to come to the elections and support the Communist Party of Russia, the party of the people and for the people" [http://www. kprf. ru/rus_soc/53430. html].

\section{Conclusions}

Like any other type of institutional discourse, a preelection discourse has universal system-forming features which are determined by the main goal of political communication, the struggle for power. The type of communication under study is distinguished from a number of existing types of discourse by the presence of its own linguistic and extralinguistic features manifested at different levels of a language: phonographic, lexical, grammatical and textual.

The above-mentioned linguistic and non-linguistic features of a pre-election discourse make it possible to 
judge the importance and significance of studying preelection discourse, for example, in order to identify ways and means of speech influence on the audience on one hand and understanding of these techniques and hidden intentions by the audience, on the other.

\section{Acknowledgement}

The work is carried out according to the Russian Government Program of Competitive Growth of Kazan Federal University.

\section{References}

[1] Bochina, T.G., Miftakhova, A.N., Malikov, A.Z. Internet as a resource of socio-linguistic researches // Social Sciences, Volume 10, Issue 5, 2015, Pages 626632.

[2] Akhmerova, L.R., Gilazetdinova, G.K. The specific features of psychological condition nomination as the discourse index in the contemporary Russian language // XLinguae. 2015. Vol. 8 №4. pp. 15-23

[3] Skorohodova E., Shutaya N., Selezneva L., Tortunova I., Rudnitskaya A. Professional discourses in information-communicative space of russia: publicistic discourse - pr discourse - business discourse // Mediterranean Journal of Social Sciences. 2015. T.6. № 5. Pp. 73-78.

[4] Poster W.R. Dangerous places and nimble fingers: discourses of gender discrimination and rights in global corporations // International Journal of Politics, Culture, and Society. 2001. T. 15. № 1. pp. 77-105.

[5] Rodny-Gumede Y. Male and female journalists' perceptions of their power to influence news agendas and public discourses // Communicatio. 2015. T. 41. № 2. C. 206-219.

[6] Sullivan J., Barner D. Discourse bootstrapping: preschoolers use linguistic discourse to learn new words // Developmental Science. 2016. T. 19. № 1. C. 63-75.

[7] Bratož, Silva, 2014, Metaphors in political discourse from a cross-cultural perspective. [na spletu]. 2014. Vol. 1, no. 7, p. 3-23.

[8] Chibuike Julius Nwosu, Fafiolu Gloria Promoting Good Governance in Nigeria through Pre-Election Discourse: The Challenges for the Media // Research on Humanities and Social Sciences.Vol.5, No.2, 2015. - pp.46-56

[9] Baranov, A. N. Introduction to applied linguistics / A.N. Baranov. - Moscow: URSS Editorial, 2001. - 360

\section{$\mathrm{p}$}

[10] Sheigal, E. I. The semiotics of political discourse / E.I. Shaygal. - Publisher: M. : Gnosis, 2004. - 326 p.

[11] Gerasimenko, N. A. Information and fascination in a political discourse / N.A. Gerasimenko // Political Discourse in Russia. - 1998. - Issue 2. - P. 20-23.

[12] Gavrilova, M. V. Political discourse as an object of linguistic analysis / M.V. Gavrilova // Polis. - 2004. - №3. - P. 127-139.

[13] Proskuryakov, M. R. Discourse of struggle (features of the language of elections) / M. R. Proskuryakov // Bulletin of the Moscow University. Ser. 9. - Philology. - 1999. - No. 1. - P. 34-49.
[14] Karasik, V. I. Language Circle: Personality, Concepts, Discourse / V.I. Karasik. - Volgograd: Change, 2002. - 477 p.

[15] Ilyin, M. V. Perspectives of political discourse analysis in Russia / M. V. Ilyin // Discourse Pi. Issue 6: Discourse of modern mythologies / Ed. by O.F. Rusakova. - Ekaterinburg, 2006. - P. 93-96. 